\title{
Hubungan Mekanisme Koping dengan Stres Pasien TB Paru di Rumah Sakit Paru Jember
}

\section{(Correlation between Coping Mechanism and Stress of Tuberculosis Patients at the Paru Hospital, Jember)}

\author{
Lie Liana Fuadiati, Erti Ikhtiarini Dewi, Enggal Hadi K. \\ Program Studi Ilmu Keperawatan Universitas Jember \\ JI. Kalimantan No. 37 Kampus Tegal Boto Jember Telp./Fax. (0331) 323450 \\ e-mail : erti_i.psik@unej.ac.id
}

\begin{abstract}
Tuberculosis is an infectious disease which can cause negative stigma from the community leading to stress of patient. Stress in tuberculosis patients may also be caused by the length of medication period as well as the side effect of the medicine. When stress affects the medication taken by the patients, the stress management is highly needed. It can be done by identifying the coping mechanism. The objective of this study was to analyze the correlation between the coping mechanism and the stress of the tuberculosis patients at the Paru Hospital, Jember. The design of this study was analytical correlational by using cross sectional approach. The population of this study was 145 patients. The sampling was 84 patients obtained by using consecutive sampling technique. The result of data analysis by Spearman correlation revealed the p-value of 0.00; r:0.529. This indicated that there is a correlation between the coping mechanism and the stress of the tuberculosis patients at the Paru Hospital Jember. It is suggested that nurses should pay attention to improve the patient's coping mechanism by providing education and counseling about tuberculosis disease and stress management. Stress management or coping can help patients to manage stress and further may complete the medication.
\end{abstract}

Keywords : Coping mechanism, stress, tuberculosis

\begin{abstract}
Abstrak
Tuberkulosis adalah penyakit menular yang dapat menyebabkan stigma negatif dari masyarakat sehingga menimbulkan stres, stres juga disebabkan oleh lamanya masa pengobatan dan efek samping obat. Ketika stres berpengaruh terhadap pengobatan yang dijalani oleh pasien TB paru, maka diperlukan manajemen stres dengan cara mengidentifikasi mekanisme koping. Tujuan penelitian ini adalah menganalisis hubungan mekanisme koping dengan stres pasien TB paru di rumah sakit Paru Jember. Desain penelitian ini adalah korelasional analitik dengan metode cross sectional. Populasi penelitian ini 145 dan sampelnya 84 responden dengan teknik sampling Consecutive Sampling. Hasil analisis data menggunakan Spearman correlation menunjukkan p-value 0,$00 ; r:-0,529$, yang menunjukkan ada hubungan mekanisme koping dengan stres Pasien TB Paru di Rumah Sakit Paru Jember. Disarankan perawat memperhatikan cara meningkatkan mekanisme koping pasien untuk menurunkan stres pasien TB paru, dengan cara pemberian edukasi dan konseling. Manajemen stres atau koping dapat membantu pasien untuk mengelola stres sehingga pasien TB paru dapat menjalankan pengobatan hingga tuntas.
\end{abstract}

Kata kunci : Mekanisme Kopina. Stres, Tuberkulosis

\section{Pendahuluan}

Tuberkulosis atau TB Paru merupakan penyakit menular [1], sehingga dampaknya yaitu stigma negatif dari masyarakat [2]. $36,29 \%$ pasien TB paru juga mengalami diskriminasi berupa pengabaian serta keengganan masyarakat berinteraksi dengan pasien TB [3]. Stigma yang dialami oleh pasien TB paru menimbulkan efek stres psikologi, depresi, ketakutan pasien TB untuk berhubungan dengan orang lain, kurangnya 
partisipasi dalam kehidupan sosial dan lain-lain [4].

Masalah lain yang dialami pasien TB paru yaitu pengobatan TB Paru membutuhkan waktu yang lama sehingga menimbulkan pasien TB mengalami bosan minum obat dan $10,06 \%$ pasien TB menghentikan pengobatan dikarenakan sudah merasa sembuh [5], ditambah lagi adanya efek samping setelah mengkonsumsi OAT (Obat Anti Tuberkulosis) [6].

Pengobatan OAT menimbulkan efek samping seperti mual, muntah, lemas, pusing, gatal, nyeri sendi, kesemutan dan warna kemerahan pada urine [7]. Tidak tuntasnya pengobatan TB Paru akan menimbulkan kebalnya kuman TB, dapat menular ke orang lain serta sulit diobatinya penyakit karena kuman menjadi kebal, sehingga membutuhkan biaya yang mahal [5]. Pengobatan yang lama akan menimbulkan peningkatan stres bagi pasien TB Paru itu sendiri [8]. Dampak dari pasien TB paru yang mengalami stres dan putus asa menyebabkan pasien TB tidak mau minum obat sehingga tidak akan sembuh dan bisa menularkan penyakitnya kepada orang lain [9].

Pada tahun 2017 terdapat 10 juta kasus baru tuberkulosis yang tersebar di wilayah Asia Tenggara (44\%), Afrika (25\%), Western Pasific $(18 \%)$, Mediterania Timur $(7,7 \%)$, Amerika (2,8\%), dan Eropa (2,7\%). 30 negara dengan beban TB tertinggi menyumbang $87 \%$ dari semua kasus yang diperkirakan di seluruh dunia, dan delapan dari negara-negara ini menyumbang dua pertiga dari total global yaitu India (27\%), Cina (9\%), Indonesia (8\%), Filipina $(6 \%)$, Pakistan (5\%), Nigeria (4\%), Bangladesh (4\%) dan Afrika Selatan (3\%) [10].

Jumlah kasus tuberkulosis di Indonesia pada tahun 2017 untuk semua tipe sejumlah 360.770 kasus dan 168.412 kasus baru yang tersebar di seluruh provinsi. Persentase kasus TB Paru untuk semua tipe di provinsi yang ada di Indonesia berdasarkan jumlah kasus per jumlah penduduk di provinsi, yang tertinggi adalah di DKI Jakarta yaitu $0,34 \%$, urutan kedua Sulawesi Utara yaitu $0,228 \%$, dan urutan ketiga Papua yaitu 0,225 \% dari seluruh jumlah penduduk provinsi tersebut. Sedangkan Jawa Timur berada diurutan ke-17 yaitu 0,12 $\%$. Setiap tahunnya selalu ditemukan kasus baru tuberkulosis, persentase kasus TB Paru untuk kasus di provinsi yang ada di Indonesia berdasarkan jumlah kasus per jumlah penduduk di provinsi, tertinggi Sulawesi Utara yaitu 0,16 , urutan kedua DKI Jakarta 0,12\% dan urutan ketiga Sulawesi Barat 0,086 \% dari seluruh jumlah penduduk. Sedangkan Jawa Timur berada diurutan ke-22 yaitu 0,057 \% [11].
Jumlah pasien TB di Kabupaten Jember semakin meningkat, pada tahun 2013 sebanyak 3.300 pasien, tahun 2014 sebanyak 3.104, tahun 2015 sebanyak 3.456, tahun 2016 sebanyak 3.325, dan tahun 2017 sebanyak 3.497 pasien [12]. Jadi setiap tahunnya jumlah pasien TB mengalami kenaikan dan penurunan di kabupaten Jember. Rumah sakit Paru Jember merupakan rumah sakit di kabupaten Jember yang berfokus pada pengobatan dan perawatan penyakit pernapasan, salah satunya TB Paru [12]. Menurut hasil studi pendahuluan yang dilakukan oleh peneliti di rumah sakit Paru Jember pada tahun 2018, jumlah kasus TB paru di rumah sakit Paru Jember pada tahun 2016 yaitu 952 kasus BTA positif dan TB paru lainnya 1.599 kasus, totalnya 2.551 kasus. Di tahun 2017 sejumlah 729 kasus BTA positif dan TB paru lainnya 1.150 kasus, totalnya 1.879 kasus. Lalu di tahun 2018, menurut laporan data di rumah sakit Paru Jember selama 3 bulan terakhir, yaitu bulan Juni, Juli, Agustus 2018 sejumlah 435 pasien di poli TB Paru, dengan rincian pasien TB paru kategori 1 (kasus baru) sejumlah 28 orang, TB paru kasus kambuh 5 orang, TB paru kategori 1 (kasus baru), kategori 2 (kasus kambuh) dan anak 54 orang, TB paru dengan HIV 6 orang, TB paru dengan diabetes mellitus 4 orang, dan sisanya TB paru disertai keluhan lainnya.

Dalam penelitian sebelumnya $86,15 \%$ pasien TB mengalami stres sedang dan $13,85 \%$ mengalami stres berat [8]. Sedangkan pada penelitian lainnya menunjukkan hampir setengah dari pasien TB yaitu $64,9 \%$ mengalami tingkat stres ringan dan $35,1 \%$ mengalami stres sedang. Selain itu efek samping dari OAT membuat pasien mengalami stres. Stres menyebabkan pasien TB paru tidak mau minum obat, resikonya mereka tidak akan sembuh dan bisa menularkan penyakitnya kepada orang lain [9]. Sebagian besar pasien TB paru mengalami tekanan emosional dan stres diakibatkan penyakitnya, dan berakibat pada penundaan perawatan serta pengobatan [4]. Perlu adanya mekanisme koping yang adaptif supaya pasien TB Paru ini dapat mengatasi stres yang mereka alami [9].

Dalam penelitian sebelumnya $70,5 \%$ pasien TB paru memiliki koping adaptif dan 29,5\% memiliki koping maladaptif. beberapa pasien TB paru masih ada yang menggunakan koping maladaptif, meskipun banyak yang sudah adaptif [13].

Penggunaan mekanisme koping yang adaptif pada pasien dengan HIV sangat membantu mereka mengatasi stres akibat penyakitnya, dalam hal ini penyakit HIV itu merupakan penyakit yang menular dan beberapa pasien dikucilkan di masyarakat 
karena dianggap penyakit yang tidak dapat disembuhkan [14]. Ada hubungan antara mekanisme koping dengan tingkat stres pada pasien kanker, untuk mengatasi stres yang dialami diperlukan mekanisme koping yang adaptif [15].

Apabila mengetahui ada tidaknya hubungan antara mekanisme koping dengan stres, perawat dan tenaga kesehatan lain dapat membantu pasien untuk meningkatkan mekanisme koping adaptif dan menurunkan stres yang dialami pasien TB Paru. Perawat diharapkan mampu menjalankan peran edukator untuk menambah pengetahuan pasien tentang penyakitnya [16], dengan bertambahnya pengetahuan tentang penyakitnya diharapkan pasien TB paru dapat berkurang stresnya sehingga pasien TB paru termotivasi untuk menjalankan program pengobatan hingga sembuh. Oleh karena itu peneliti ingin mengetahui apakah ada hubungan mekanisme koping dengan stres pada pasien TB paru.

\section{Metode Penelitian}

Desain penelitian pada penelitian ini adalah Korelasional analitik dengan pendekatan cross sectional. Populasi dalam penelitian ini adalah seluruh pasien yang didiagnosa TB paru dan menjalani pengobatan rawat jalan di rumah sakit Paru Jember. Teknik sampling menggunakan teknik non probability sampling yaitu dengan jumlah sampel 84 responden dengan kriteria inklusi yaitu pasien TB paru yang sedang dalam masa pengobatan rawat jalan di poli TB rumah sakit Paru Jember, berumur 15-60 tahun dan bersedia menjadi responden dalam penelitian, dan dengan kriteria eksklusi yaitu pasien TB-MDR, TB dengan penyakit penyerta seperti diabetes mellitus, HIVIAIDS, stroke, gagal ginjal dan lain-lain. Alat pengumpulan data menggunakan kuesioner DASS 42 dan Brief Cope yang telah dilakukan uji validitas. Data dianalisis menggunakan Spearman test untuk mengetahui hubungan mekanisme koping dengan stres pasien TB paru di rumah sakit Paru Jember. Data penelitian diambil menggunakan lembar permohonan (Informed), lembar persetujuan penelitian (Consent), kerahasiaan (Privacy), keadilan (Justice), dan kemanfaatan (Beneficience).

\section{Hasil}

Hasil penelitian ditampilkan dalam bentuk narasi dan tabel. Data hasil penelitian dibedakan menjadi dua, yaitu data umum dan data khusus. Data umum berisi tentang hasil analisis univariat dari karakteristik sampel penelitian yaitu usia, jenis kelamin, dan lama pengobatan. Data khusus terdiri dari variabel penelitian yaitu mekanisme koping dan stres pasien TB paru di rumah sakit Paru Jember.

Karakteristik Sampel Penelitian

Tabel 1. Distribusi Data Karakteristik Responden berdasarkan Umur pada pasien TB Paru di Rumah Sakit Paru Jember pada bulan Januari 2019 $(n=84)$

\begin{tabular}{cccc}
\hline & Median & Mean & Min-Max \\
\hline Umur & 36,00 & 35,30 & $16-59$ \\
\hline
\end{tabular}

Tabel 1 menunjukkan bahwa distribusi responden menurut umur memiliki nilai ratarata 35,30 , nilai tengah 36 dan umur minimal responden 16 tahun sedangkan umur maksimal responden adalah 59 tahun.

Tabel 2. Distribusi Responden Berdasarkan Jenis Kelamin dan Lama Pengobatan pada pasien TB Paru di Rumah Sakit Paru Jember pada bulan Januari $2019(n=84)$

\begin{tabular}{lcc}
\hline \multicolumn{1}{c}{ Variabel } & Jumlah & $\begin{array}{c}\text { Persentase } \\
(\%)\end{array}$ \\
\hline $\begin{array}{l}\text { Jenis Kelamin } \\
\text { Laki-laki }\end{array}$ & 33 & 39,3 \\
Perempuan & 51 & 60,7 \\
\hline Total & 84 & 100 \\
\hline Lama & & \\
Pengobatan & 27 & 32,1 \\
< 2 bulan & 48 & 57,1 \\
2-6 bulan & 6 & 7,1 \\
7-8 bulan & 3 & 3,6 \\
> 8 bulan & & \\
\hline Total & 84 & 100 \\
\hline
\end{tabular}

Tabel 2 menunjukkan bahwa dari 84 responden yang memiliki jenis kelamin perempuan lebih banyak yaitu 51 orang $(60,7 \%)$. Berdasarkan umur menunjukkan bahwa responden rata-rata berumur 35 tahun. Berdasarkan lama pengobatan menunjukkan bahwa responden terbanyak sedang menjalani pengobatan selama 2-6 bulan yaitu 48 orang $(57,1 \%)$.

Tabel 3. Distribusi Frekuensi Mekanisme Koping pada Pasien TB Paru di Rumah Sakit Paru Jember bulan Januari $2019(\mathrm{n}=84)$

\begin{tabular}{lcc}
\hline \multicolumn{1}{c}{ Variabel } & Jumlah & $\begin{array}{c}\text { Persentase } \\
(\%)\end{array}$ \\
\hline $\begin{array}{l}\text { Mekanisme } \\
\text { Koping } \\
\text { a. Mekanisme }\end{array}$ & 70 & 83,3 \\
\hline
\end{tabular}




\begin{tabular}{lll}
\hline Koping & 14 & 16,7 \\
$\begin{array}{l}\text { Adaptif } \\
\text { b. Mekanisme } \\
\text { Koping } \\
\text { Maladaptif }\end{array}$ & & \\
\hline Total & 84 & 100,0 \\
\hline
\end{tabular}

Tabel 3 menunjukkan bahwa pasien TB Paru di rumah sakit Paru Jember lebih banyak memiliki mekanisme koping adaptif yaitu 70 orang $(83,3 \%)$ sedangkan paling sedikit memiliki mekanisme koping maladaptif yaitu 14 orang $(16,7 \%)$.

Tabel 4. Rerata Mekanisme Koping dan Indikator Mekanisme Koping pada Pasien TB Paru di Rumah Sakit Paru Jember bulan Januari $2019(n=84)$

\begin{tabular}{lcc}
\hline \multicolumn{1}{c}{ Indikator } & Mean & SD \\
\hline Mekanisme Koping & & \\
Problem Focused & 76,17 & 1,46 \\
Coping & 2,68 & 0,66 \\
Emotion-Focused & 2,80 & 0,57 \\
Coping & 2,66 & 0,47 \\
Dysfunctional Coping & & \\
\hline
\end{tabular}

Tabel 4 menunjukkan bahwa distribusi responden menurut mekanisme koping memiliki rata-rata 76,17 dengan standart deviasi 1,46, yang artinya rata-rata mekanisme koping yang dimiliki responden adaptif. Nilai rerata indikator mekanisme koping paling tinggi pada indikator Emotion Focused Coping yaitu 2,80 dengan standart deviasi 0,57 . Dan nilai rerata paling rendah pada indikator Dysfunctional Coping yaitu 2,66 dengan standart deviasi 0,47.

Tabel 5. Distribusi Frekuensi Stres pada Pasien TB Paru di Rumah Sakit Paru Jember bulan Januari $2019(n=84)$

\begin{tabular}{lcc}
\hline \multicolumn{1}{c}{ Variabel } & Jumlah & $\begin{array}{c}\text { Persentase } \\
(\%)\end{array}$ \\
\hline Stres & 25 & 29,8 \\
Normal & 44 & 52,4 \\
Stres Ringan & 11 & 13,1 \\
Stres Sedang & 4 & 4,8 \\
Stres Parah & 0 & 0 \\
Stres Sangat & & \\
Parah & & 100,0 \\
\hline Total & 84 & \\
\hline
\end{tabular}

Tabel 5 menunjukkan bahwa pasien TB Paru di rumah sakit Paru Jember yang menjadi responden lebih banyak mengalami stres ringan yaitu 44 orang $(52,4 \%)$, sedangkan paling sedikit mengalami stres parah yaitu 4 orang $(4,8 \%)$, dan tidak didapatkan responden yang mengalami stres sangat parah.
Tabel 6. Rerata Stres dan Indikator Stres pada Pasien TB Paru di Rumah Sakit Paru Jember (Januari 2019; $n=84$ )

\begin{tabular}{lcc}
\hline \multicolumn{1}{c}{ Indikator } & Mean & SD \\
\hline Stres & 15,04 & 6,26 \\
Gejala Fisik & 1,13 & 0,60 \\
Gejala Psikologis & 0,96 & 0,52 \\
Gejala Emosional dan & 1,14 & 0,49 \\
Perilaku & & \\
\hline
\end{tabular}

Tabel 6 menunjukkan bahwa distribusi responden menurut stres memiliki rata-rata 15,04 dengan standart 6,26, yang artinya ratarata stres yang dialami responden yaitu stres ringan. Nilai rerata indikator stres paling tinggi pada indikator gejala emosional dan perilaku yaitu 1,14 dengan standart deviasi 0,49. Dan rerata indikator stres paling rendah pada indikator gejala psikologis yaitu 0,96 dengan standart deviasi 0,52.

Tabel 7. Analisis Hubungan Mekanisme Koping dengan Stres Pasien TB Paru di Rumah Sakit Paru Jember

\begin{tabular}{lcc}
\hline \multicolumn{1}{c}{ Variabel } & $p$-value & $\mathrm{R}$ \\
\cline { 1 - 1 } Mekanisme Koping & 0,00 & $-0,529$ \\
\hline Stres & & \\
\hline
\end{tabular}

Tabel 7 menunjukkan uji Spearman's rho didapatkan bahwa terdapat hubungan antara mekanisme koping dengan stres dengan $p$ value 0,00 dan nilai korelasi sebesar - 0,529 yang menunjukkan bahwa korelasinya tergolong sedang. Arah korelasi negatif menunjukkan semakin adaptif mekanisme koping maka semakin ringan stres yang dialaminya, begitu juga sebaliknya semakin maladaptif mekanisme koping maka semakin parah stres yang dialaminya.

\section{Pembahasan \\ Karakteristik Pasien TB Paru di Rumah Sakit Paru Jember}

Rata-rata pasien TB Paru di Rumah Sakit Paru Jember pada tabel 1 berumur 35 tahun (usia produktif) dan umur minimal responden 16 tahun sedangkan umur maksimal responden adalah 59 tahun. Penelitian ini sesuai dengan hasil penelitian sebelumnya bahwa pada usia 17-55 tahun lebih banyak ditemukan pasien TB paru $(90,9 \%)$ [7]. TB paru lebih banyak menyerang pada usia produktif, penyebabnya pada usia produktif ini manusia bekerja dan lingkungan kerja yang berhubungan dengan banyak orang dan padat maka resiko terjadinya penularan TB paru menjadi lebih mudah. Ditambah lagi kelompok 
umur yang memiliki mobilitas tinggi yaitu umur 15-55, akibatnya pada umur tersebut lebih mudah terpapar Mycobacterium Tuberculosis. Peneliti juga berpendapat bahwa usia produktif lebih mudah tertular TB paru dikarenakan mobilitas yang sangat tinggi pada usia $15-55$ tahun dan di usia tersebut mulai bekerja dan berhubungan dengan banyak orang semakin meningkatkan resiko terpapar Mycobacterium Tuberculosis [17].

Karakteristik jenis kelamin pada tabel 2 menunjukkan bahwa pasien TB Paru di Rumah Sakit Paru Jember lebih banyak berjenis kelamin perempuan yaitu 51 orang $(60,7 \%)$. Penelitian ini sesuai dengan hasil penelitian sebelumnya bahwa perempuan lebih banyak $(63,64 \%)$ mengalami penyakit TB dari pada laki-laki (36,36\%), dikarenakan, hal tersebut dimungkinkan saat pengambilan data di periode tersebut banyak pasien perempuan yang berobat [7].

Namun hasil ini sedikit berbeda dengan penelitian lainnya, bahwa penderita TB paru lebih banyak berjenis kelamin laki-laki $(64,1 \%)$ dikarenakan pola hidup laki-laki yang kurang sehat seperti merokok dan mimun minuman beralkohol yang menyebabkan turunnya sistem pertahanan tubuh [18]. Laki-laki lebih beresiko terkena penyakit TB paru dibandingkan perempuan dikarenakan kebanyakan laki-laki bekerja di luar rumah sehingga mudah terpapar oleh Mycobacterium Tuberculosis. Lalu faktor resiko lainnya kebanyakan laki-laki merokok dan minum alkohol, sedangkan pada perempuan jarang. Hal tersebut menimbulkan menurunnya imunitas tubuh sehingga mudah terkena penyakit TB paru [17].

Peneliti berpendapat mengapa hasil penelitian peneliti lebih banyak pasien berjenis kelamin perempuan. Kemungkinan pada saat pengambilan sampel oleh peneliti di periode tersebut banyak pasien perempuan yang sedang mengambil obat. Ketika pasien perempuan berobat, pasien tersebut ditemani oleh suami dan keluarganya, namun ketika pasien laki-laki sakit ia tidak dapat datang ke rumah sakit sehingga untuk pengambilan obat diwakilkan oleh anak atau keluarganya. Hal tersebut juga mungkin terjadi dikarenakan lakilaki sedang bekerja karena laki-laki merupakan pencari nafkah.

Berdasarkan lama pengobatan menunjukkan bahwa responden terbanyak sedang menjalani pengobatan selama 2-6 bulan yaitu 48 orang $(57,1 \%)$. Hasil ini sesuai dengan penelitian Sari (2018) bahwa lama pengobatan sebagian besar responden $(54,84 \%)$ adalah $\geq 3$ bulan. Jumlah kasus tuberkulosis di Indonesia pada tahun 2017 untuk semua tipe sejumlah 360.770 kasus dan
168.412 kasus baru yang tersebar di seluruh provinsi. Jadi setiap tahunnya selalu ditemukan kasus baru tuberkulosis [11]. Kesadaran diri pasien, motivasi dan dukungan keluarga akan mempengaruhi kepatuhan berobat pasien TB Paru [19].

Hasil penelitian menunjukkan bahwa mayoritas pasien TB paru di rumah sakit Paru Jember adalah pasien dengan kasus baru sehingga sebagaian besar pasien menjalani pengobatan kategori 1 (2-6 bulan). Pengobatan kategori 1 merupakan pengobatan tuberkulosis yang terdiri dari 2 fase yaitu fase intensif (2 bulan) dan fase lanjutan (4 bulan) [20].

Peneliti berpendapat masih adanya pasien TB Paru yang belum berobat sehingga menularkan penyakitnya kepada orang lain, meskipun sudah banyak pasien yang sudah sadar untuk berobat. Oleh karena itu mengapa setiap tahunnya selalu ditemukan kasus baru TB paru, selain itu pengobatan yang tidak tuntas akan menyebabkan pasien tidak sembuh dan dapat menularkan penyakitnya kepada orang lain. Oleh karena itu setiap tahunnya selalu ditemukan kasus baru TB paru.

\section{Mekanisme Koping Pasien TB Paru di Rumah Sakit Paru Jember}

Mekanisme koping pada pasien TB Paru di rumah sakit Paru Jember pada tabel 3 menunjukkan sebagian besar menggunakan mekanisme koping adaptif $(83,3 \%)$ dan lebih sedikit menggunakan mekanisme koping maladaptif $(16,7 \%)$. Hasil tersebut sesuai dengan penelitian sebelumnya bahwa pasien TB paru lebih banyak yang memiliki mekanisme koping adaptif $(70,5 \%)$ dan yang memiliki koping maladaptif lebih sedikit $(29,5 \%)$ [13]. Beberapa koping pasien TB paru masih ada yang maladaptif, meskipun banyak yang sudah adaptif.

Apabila individu bersikap positif terhadap masalah dan memiliki keyakinan positif maka individu tersebut akan dapat mengendalikan stres yang dialami. Selain itu dengan mengendalikan faktor penyebab stres yaitu menyadari (awarenes skills), menerima (acceptance skills), mengahdapi (coping skills) dan bertindak (action skills) maka masalah dapat terselesaikan sehingga dapat mengurangi stres [21]. Peneliti berpendapat bahwa seseorang yang menderita suatu penyakit dan menerima tekanan tidak selalu membuat seseorang memiliki koping maladaptif, koping tergantung bagaimana cara individu memandang suatu masalah, bagaimana cara menyelesaikannya dan kemampuan untuk menyadari serta menerima keadaannya. 
Hasil dari indikator mekanisme koping menunjukkan bahwa rata-rata tertinggi yaitu pada indikator Emotion Focused Coping dengan mean 2,80 dan standart deviasi 0,57. Emotion Focused Coping dilakukan dengan cara menerima kondisi saat ini, mengkaji strategi koping, lebih dekat dengan Tuhan, dan menggunakan dukungan emosional yang dilakukan untuk mengontrol efek yang disebabkan oleh stres. Hasil ini sesuai dengan penelitian sebelumnya bahwa emotion-focused coping merupakan strategi koping yang digunakan individu mengalami stres dengan cara menerima masalah yang sedang terjadi. Dengan cara menerima maka emosi positif (menerima, senang) akan muncul dan menghilangkan emosi negatif (sedih, cemas, marah), hal tersebut juga dilakukan untuk mengurangi reaksi yang disebabkan oleh stres [22].

Emotion Focused Coping merupakan respon emosional seseorang uang ditunjukkan dengan perilaku kognitif dalam mengatasi stresor yang diakibatkan penyakitnya, dengan cara menerima kenyataan terhadap masalah yang telah terjadi, berdoa dan beribadah kepada Tuhan untuk memohon bantuan ketika menghadapi suatu masalah, mencari dukungan secara moral, pengertian dari orang lain, simpati untuk mengurangi perasaan tidak nyaman [23]. Peneliti berpendapat bahwa dengan Emotion Focused Coping ketika mengahdapi suatu masalah yang menimbulkan stres, maka individu akan lebih mampu mengelola stres yang dihadapi. Apabila individu dapat menerima kondisinya, maka ia akan menjadi lebih tenang dan emosi positif muncul. Ketika lebih tenang maka individu akan mampu memikirkan apa yang harus dilakukan untuk mengatasi masalah yang dihadapi sehingga mengurangi stres akibat masalah yang terjadi.

\section{Stres Pasien TB Paru di Rumah Sakit Paru Jember}

Sebagian besar pasien TB Paru di Rumah Sakit Paru Jember berada dalam kategori stres ringan $(52,4 \%)$. Penelitian ini sesuai dengan penelitian sebelumnya hampir setengah dari pasien TB yaitu 64,9\% mengalami tingkat stres ringan, beberapa pasien TB paru sudah mengerti cara mengelola stres sehingga koping yang dimiliki menjadi konstruktif dan dapat mengatasi masalah yang mereka alami serta terbebas dari stres, cemas dan depresi [9].

Penelitian tersebut berbeda dengan penelitian lainnya bahwa $86,15 \%$ pasien TB mengalami stres sedang dan 13,85\% mengalami stres berat [8]. Dikarenakan stres yang dialami seseorang berbeda-beda setiap individu tergantung respon setiap individu dalam menghadapi stres yang dialaminya [24]. Peneliti berpendapat bahwa ringan atau parahnya stres yang dialami seseorang bergantung pada cara individu dalam menghadapi masalah dan menyesuaikan diri dengan masalah yang dihadapi, semakin baik seseorang dalam menghadapi masalah maka stres yang dialami akan semakin ringan. Ketika seseorang memandang suatu masalah sebagai musibah, maka yang dirasakan hanya kesedihan dan hal tersebut menimbulkan pikiran negatif sehingga menyebabkan stres. Sebaliknya apabila seseorang memandang masalah secara positif maka ia akan dapat mengambil hikmah dari masalah yang dialami. Misalnya dengan sakit yang dialami sisi negatifnya tidak bisa bekerja dan harus berobat, namun sisi positifnya waktu bersama keluarga menjadi banyak dan lebih menjaga kesehatan.

Hasil dari indikator stres yang memiliki rata-rata tertinggi yaitu pada indikator gejala emosional dan perilaku. Stres yang dialami seseorang dapat mempengaruhi emosi dan perilaku seseorang misalnya mudah marah, bereaksi berlebihan terhadap suatu situasi, tidak sabar, menghabiskan banyak energi ketika cemas dan tidak bisa menerima terhadap sesuatu yang bisa menghalanginya. Gejala tersebut terjadi karena pelampiasan individu untuk mengurangi perasaan tidak nyaman yang dialami. Hal ini sesuai dengan penelitian sebelumnya bahwa kondisi stres mendorong terjadinya perubahan emosi dan perilaku seseorang seperti perasaan marah, frustasi, putus asa, penurunan minat, mengekspresikan dengan cara pandangan sinis terhadap orang lain, perasaan kecewa, marah dan penurunan energi [25]. Gejala Emosional dan Perilaku yang muncul akibat stres akan menyebabkan seseorang mudah marah terhadap hal-hal sepele, bereaksi berlebihan terhadap situasi, mudah jengkel dan kesal, ketika mengalami suatu yang tertunda tidak sabar, dan ketika keinginannya terhalangi oleh sesuatu maka tidak bisa menerima hal tersebut [18].

Respon individu terhadap stres yaitu respon kognitif, afektif, fisiologis, perilaku dan sosial. Respon afektif ditunjukkan dengan mudah marah, cemas berlebihan, gelisah, dan putus asa. Sedangkan respon perilaku ditunjukkan dengan kurangnya kemampuan untuk mengontrol diri [24]. Peneliti berpendapat bahwa gejala emosional dan perilaku yang muncul merupakan respon individu menghadapi stres, hal tersebut juga merupakan cara individu mengurangi perasaan tidak nyaman dengan cara meluapkan emosi. 


\section{Hubungan Mekanisme Koping dengan Stres Pasien TB Paru di Rumah Sakit Paru Jember}

Hasil analisa bivariat dari kedua variabel tersebut menunjukkan bahwa ada hubungan antara mekanisme koping dengan stres pasien TB paru di rumah sakit Paru Jember dengan $p$ value 0,00 dan nilai koefisien korelasi $(r)$ sebesar $-0,529$. Hasil ini menunjukkan bahwa hubungan antara variabel keduanya tergolong sedang dan bernilai negatif, yang artinya semakin adaptif mekanisme koping maka semakin ringan stres yang dialami. Nilai koefisien korelasi mendekati satu maka hubungan kedua variabel akan semakin kuat dan jika mendekati nol maka hubungan kedua variabel akan semakin lemah [26].

Pengelolaan stres atau mekanisme
koping dapat membantu individu menghilangkan, mengurangi, mengatur dan mengelola stres yang dialami. Koping juga menjadi usaha individu dalam mempertahankan penyesuaian diri terhadap situasi yang menyebabkan stres [27]. Untuk mengatasi stres yang dialami diperlukan mekanisme koping yang adaptif, dengan mekanisme koping yang adaptif maka stres yang dialami akan semakin ringan [15].

Dengan mengetahui penyebab stres maka dapat digunakan untuk mengatasi stres yang dialami. Penggunaan mekanisme koping yang adaptif sangat membantu pasien untuk mengatasi stres akibat penyakitnya. Dengan koping adaptif maka dapat meningkatkan pemikiran yang positif dan perilaku positif seperti berhenti merokok, gaya hidup sehat, aktivitas fisik dan nutrisi yang tepat, tidur yang cukup. Perilaku positif tersebut dapat meningkatkan kesehatan pasien, apabila kesehatan dan kondisi fisik pasien baik maka stres juga akan berkurang [14]. Peneliti berpendapat bahwa mekanisme koping memiliki hubungan berlawanan arah dengan stres, semakin adaptif mekanisme koping yang dimiliki seseorang maka semakin ringan stres yang dialami. Peneliti berpendapat bahwa koping menjadi usaha individu untuk beradaptasi dengan situasi yang membuat tertekan dan stres, ketika individu mampu beradaptasi maka stres tidak akan terjadi.

Stres juga bergantung bagaimana individu memandang suatu masalah. Ketika seseorang memandang suatu masalah sebagai musibah, maka yang dirasakan hanya kesedihan dan hal tersebut menimbulkan pikiran negatif sehingga menyebabkan stres. Ditambah lagi dengan sedih terus menerus maka sulit untuk memikirkan langkah apa yang harus diambil dalam menghadapi masalah. Sebaliknya apabila seseorang memandang masalah secara positif maka ia akan dapat mengambil hikmah dari masalah yang dialami. Misalnya dengan sakit yang dialami sisi negatifnya tidak bisa bekerja dan harus berobat, namun sisi positifnya waktu bersama keluarga menjadi banyak dan lebih menjaga kesehatan.

Selain itu koping adaptif juga dapat dilakukan dengan cara menerima kondisi penyakit, dengan menerima maka individu akan lebih merasa tenang. Ketika merasa tenang stres yang dialami juga akan berkurang. Ditambah lagi ketika merasa tenang maka individu akan mampu berpikir jernih tentang apa yang harus dilakukan ketika menghadapi masalah.

\section{Simpulan dan Saran}

Berdasarkan hasil penelitian dan pembahasan terkait hubungan antara mekanisme koping dengan stres pasien TB paru di rumah sakit Paru Jember, maka dapat ditarik kesimpulan bahwa ada hubungan yang signifikan antara mekanisme koping dengan stres pasien TB paru di rumah sakit Paru Jember.

Diharapkan bagi perawat memperhatikan cara meningkatkan mekanisme koping pasien untuk menurunkan stres pasien TB paru. Perawat dapat memberikan konseling, terapi psikologis dan edukasi tentang penyakit serta manajemen stres yang dapat membantu meningkatkan mekanisme koping adaptif untuk mengurangi stres. Supaya pasien TB paru dapat menjalankan pengobatan hingga tuntas.

\section{Daftar Pustaka}

[1] Price dan Wilson. Patofisiologi konsep klinis proses-proses penyakit. Jakarta: EGC; 2006.

[2] Hidayati E. Pengetahuan dan stigma masyarakat terhadap TBC setelah diberikan pendidikan kesehatan mengenai pencegahan dan penularan. Soedirman $\mathrm{J}$ Nurs [Internet]. 2015;10, No.2(1):17-23. Available

from: http://jks.fikes.unsoed.ac.id/index.php/jks/a rticle/view/185/86gmbran

[3] Sari Y. Gambaran stigma diri klien tuberkulosis paru (tb paru) yang menjalani pengobatan di Puskesmas Malingping. Media Ilmu Kesehatan. 2018;7(1):43-50.

[4] Moya EM. Tuberculosis and stigma: impacts on health-seeking behaviors and access in Ciudad Juarez, Mexico and El Paso, Texas. Diss Abstr Int Sect A Humanit Soc Sci [Internet]. 2010;71(7A):2361.Available from:http://ovidsp.ovid.c om/ovidweb.cgi?T=JS\&PAGE=reference\& $D=p s y c 8 \& N E W S=N \& A N=2011-99010-120$ 
[5] Suharmiati, Maryani H. Analisis hubungan penggunaan obat FDC / Kombipak pada penderita yang didiagnosis TB paru berdasarkan karakteristik. Bul Penelit Sist Kesehat. 2011;14, No.2:167-73.

[6] Chrisnawati, Beda VM, Maratning A. pengalaman hidup pasien tuberkulosis yang menjalani pengobatan OAT (obat anti tuberkulosis) di wilayah kerja Puskesmas Pekauman Banjarmasin Tahun 2017. Water Resour Rural Dev [Internet]. 2017;9(March):1-14. Available from:http://dx.doi.org/10.1016/j.wrr.2017.0 4.001

[7] Farhanisa, Untari EK, Nansy E. Kejadian efek samping obat anti tuberkulosis (OAT) kategori 1 pada pasien tb paru di unit pengobatan penyakit paru-paru (UP4) Provinsi Kalimantan Barat. Program Studi Farmasi Universitas Tanjungpura. 2015;17.

[8] Aliflamra I, Wati YR, Rahimah dan SB. Hubungan lama pengobatan dengan tingkat stres pada pasien tuberkulosis paru di RSUD Al - Ihsan kabupaten Bandung periode Maret - Mei 2016. Pros Pendidik Dr. 2016;2(2):746-51.

[9] Suryani EW, Hernawati T, Sriati A. Psikoedukasi menurunkan tingkat depresi, stres dan kecemasan pada pasien tuberkulosis paru. J Ners. 2016;11(1):12833.

[10] WHO. Global tuberculosis report. 2018;32-37.

[11] Kementrian Kesehatan Republik Indonesia. Profil kesehatan Indonesia 2017. Data dan informasi profil kesehatan Indonesia $2017 \quad$ [Internet]. 2018; Available from:http://www.pusdatin.k emkes.go.id/resources/download/pusdatin/ profil-kesehatan-indonesia/Data-danInformasi_Profil-Kesehatan-Indonesia2017.pdf

[12] Dinas Kesehatan Kabupaten Jember. Dukungan daerah dalam program percepatan eliminasi TB di kabupaten Jember - Jawa Timur. 2018;

[13] Sitorus FE, Barus DT. Hubungan koping stres dengan kepatuhan minum obat pada penderita tuberkulosis paru. J Keperawatan Fisioterapi. 2018;1(1):1-6.

[14] Mahmoudi M, Dehdari T, Shojaeezadeh D, Abbasian L. Coping with stress strategies in hiv-infected iranian patients. J Assoc Nurses AIDS Care [Internet]. 2015;26(4):464-71. Available from:http://dx.doi.org/10.1016/j.jana.2015.0 1.001.

[15] Mariana A. Hubungan mekanisme koping dengan tingkat stres pada pasien kanker di unit radioterapi RSUP Dr.M.Djamil Padang. Skripsi. 2014;40.

[16] Suryadi FR. Hubungan peran educator perawat dalam discharge planning dengan tingkat kepatuhan pasien rawat inap untuk kontrol di Rumah Sakit Paru Kabupaten Jember. 2013;

[17] Dotulong JFJ, Sapulete MR, Kandou GD. Hubungan faktor risiko umur, jenis kelamin dan kepadatan hunian dengan kejadian penyakit TB Paru di desa Wori kecamatan Wori. J Kedokt Komunitas dan Trop [Internet].2015;3(2):57-65.

Available from:https://ejournal.unsrat.ac.id/ index.php/JKKT/article/download/7773/733 6

[18] Noviani W. Digital Repository Universitas Jember. Hubungan tingkat stres dengan efikasi diri pada pasien TB Paru di wilayah kerja puskesmas Patrang kabupaten Jember. Skripsi. 2018;100.

[19] Muna L, Soleha U. Motivasi dan dukungan sosial keluarga mempengaruhi kepatuhan berobat pada pasien TB Paru di poli paru BP4 Pamekasan. J Ilmu Kesehatan. 2014;4:172-9.

[20] Muttaqin A. Buku ajar asuhan kperawatan klien dengan gangguan sistem pernapasan [Internet]. Jakarta: Salemba Medika; 2008. Available from: https://books. google.co.id/books?id=G3KX ne15oqQCdanpg=PA79dandq=pencegaha $\mathrm{n}+$ tuberkulosisdanhl=endansa $=\mathrm{X}$ danved $=0$ ahUKEwi09fjTgsXdAhVGsI8KHRJuD1EQ6 $A E I M D A B \# v=$ onepagedanq=pencegahan tuberkulosisdanf=true

[21] Sunaryo. Psikologi untuk keperawatan. Jakarta: EGC; 2004.

[20] Worthington EL, Scherer M. Forgiveness is an emotion-focused coping strategy that can reduce health risks and promote health resilience: theory, review, and hypotheses risks and promote health resilience: Psychology Health. 2007;385405(November 2014):37-41.

[23] Arfina A. Hubungan mekanisme koping dan disabilitas dengan keputusasaan pada pasien stroke di rumah sakit kota Medan. Tesis. 2017;(X):212.

[24] Stuart dan Laraia. Buku saku keperawatan jiwa. 5th ed. jakarta: EGC; 2007.

[25] Christyanti D, Mustami'ah D, Sulistiani W. Hubungan antara penyesuaian diri terhadap tuntutan akademik dengan kecendrungan stress pada mahasiswa Fakultas Kedokteran Universitas Hang Tuah Surabaya. Google Cendikia. 2010;12(03):153-9.

[26] Zulfikar, Budiantara IN. Manajemen riset dengan pendekatan komputasi statistika. 
Fuadiati, et al., Hubungan Mekanisme Koping dengan Stres Pasien TB Paru di ...

2014. 100-101 p.

[27] Kholida EN, Alsa A. Berpikir positif untuk menurunkan stres psikologis. J Psikologi [Internet]. 2012;39(1):67-75. Available from:http://jurnal.psikologi.ugm.ac.id/index. $\mathrm{php/fpsi/article/view/180}$ 